\title{
FISCAL MANAGEMENT IN INDONESIA: THE PERSPECTIVE OF POLITICAL-ECONOMY INFORMATION
}

\author{
Agung Darono ${ }^{1}$ \\ Financial Education and Training Board, Ministry of Finance, Indonesia
}

\begin{abstract}
Fiscal management is an effort to formulate fiscal policies to be implemented, controlled, and responsible based on the government regulation. For this purpose, fiscal authority undoubtedly needs an adequate support from the country's financial information. The provision of information for the sake of this fiscal management cannot only be seen as an issue of economic-information which tends to emphasize on the process of information allocation, production, distribution, and consumption as an economic commodity. Using a conceptual framework of political-economy information, the information provision in the context of fiscal management is more of a constellation of various existing economic-information that should be correlated with the involved actors, and comprehensively take into account the surrounding social-political structure. By employing an interpretive policy analysis as the data analysis approach, this study finds that fiscal authority in Indonesia has gradually made a number of efforts to improve the mechanism of the nation's financial information provision for those who have fiscal management interests, either from income information (tax/non-tax) or expenditure information. In some conditions, it is identified that the initiative of information provision for the advantage of fiscal management as well as its implementation requires proper political support.
\end{abstract}

Keywords: Fiscal Management, Political-Economy Information, Interpretive Policy Analysis

JEL Classifications: H30, H60

\section{INTRODUCTION}

During the economic crisis of 1997-1998, the Indonesian government decided to call for a monetary assistance from the International Monetary Funds (IMF) as part of the recovery program. Indonesia, as a country in need for assistance, was required to fulfill some conditions proposed by the IMF. One of the important documents, namely Memorandum of Economic and Financial Policies (MEFP), stated that the Indonesian Government agreed to develop a system of the electronic application which could

\footnotetext{
${ }^{1}$ This study is not related to any premises or policies of the institute where the author works.
} 
handle income (through tax/toll/excise duty) and spending of the country. Relating to income, it was stated that:

"June 2003, the electronic tax filing and payment system will be expanded to process 75 per cent of DGT tax collections. The electronic payment system will also be introduced at one large customs office and one large budget office to process the remittance of import duties and taxes collected or withheld by these offices." (IMF, 2003).

Meanwhile, it was also mentioned relating to budgeting and spending sides:

“... Once the blueprint is in place, the government intends to establish dedicated task forces by July to review the reform of the government's payment and receipts system, consolidation of bank accounts, and the restructuring of budget preparation procedures." (IMF, 2003)

This study has no intention to bring back the discussion about the economic crisis, but it tries to make it as a sign or a milestone, particularly for fiscal management in Indonesia. The MEFP document itself can be regarded as a sign or a "manifesto" of the presence of a political-economy of information study in Indonesia. This document has also implicitly showed that the political-economy of information (in reference to Homburg (2000) for example) exists in Indonesia, particularly in the case of fiscal management in Indonesia.

What interesting to note from the previous situation during the crisis is how a technical artefact in the study of economic information (such as the request of IMF to develop the tax payment system electronically) can be a clause as prerequisite in an agreement involving a country with international donor institution (IMF in this case). Therefore, what used to be considered as the technical artefacts, it has also become political artefacts. As a consequence, the analysis tool to comprehend these matters required a wider conceptual framework than the one offered by the political-economy framework (see for instance: Verzola (2006); Porat (1977)) or political information (refer to e.g. Strassman (1994); Davenport et.al (1992)). A variety of concepts from those fields can be integrated to a more comprehensive analytical framework as a conceptual framework of the so-called political-economy information, in the same manner as offered by O'Brien and Helleiner (1980), Salter (1993), Homburg (2000), or Benkler (2003).

The next question is whether the constellation of political-economy information related to the fiscal management requested by IMF as the prerequisite will remain exist after Indonesia left the recovery program of the IMF. According to Sadli (2003) and 
Kompas (2003), there was a political decision expectation that Indonesia cut the bond with the IMF in an attempt to recover from the economic crisis. This can be seen in the People's Consultative Assembly (Majelis Permusyawaratan Rakyat/MPR) decree No. VI/MPR/2002, which declared that Indonesia will leave the IMF program without having to trigger any potential monetary chaos by no later than December 2003.

This study, therefore, attempts to review a number of facts concerning these phenomena. It aims at explaining how the aspects of economic-information and political information interplay the constellation of information support as a tool in the decision making of fiscal management in Indonesia during period of 2004-2014.

The structure of this paper is as follows. The introduction section presents the background and the purpose of the study. The second part explains the previous literature used in this study. Section three discusses the research method used in this study. In the following section, this paper discusses the results based on the author's viewpoint using inter-case analysis. Finally, it will provide conclusion as well as recommendation.

\section{LITERATURE REVIEW}

\section{Political-Economy Information}

According to Deliarnov (2006), the study of classical economics has several limitations because it considers market as the most efficient media for economic resource allocation. In fact, market sometimes fails to achieve the effecient allocation. As a consequence, it is necessary for the economics to extend their scope by inserting the political aspect. In this case, a study of political economy is analyses of a group of economic parameters or variables and the roles of actors involved that consider the structure of the surrounding social-political issues.

Oppenheimer (1980) explained that politics is never possible to be separated from the economics. Politicians always take the economic factors into consideration in their political justification. World Bank (2008) also pointed out that political-economy is a study about political-process and economic-variables. The detailed of their explanation is as follow.

"Today, the term is defined as analysis that studies the linkages between politics and economics, drawing on theories of economics, law as well as political and social 
sciences. Economic theory traditionally focuses on market decisions, where voluntary exchange leads to Pareto efficient outcomes. The decisions that political economy focuses on are those where the market does not produce these desired outcomes - for example, in the case of over-exploitation of land/resources due to unclear tenure - as they are influenced by political and not economic considerations."

As pointed out by Porat (1977) and Verzola (2006), studies on economics have to take into account the study of economic-information which in particular discusses "information" as a unique economic factor. Verzola (2006) explained the unique characteristics of information as an economic factor compared to factors in other economic sectors, such as manufacturing or energy economics, are: (1) information as an economic good has a nature of temporary scarcity, that is, when it is produced for the first time, but then it can be reproduced on a very minimum cost (near-zero marginal cost of production) ; (2) as the consequence of this nature, the mechanism of ownership protection of information, the so called intellectual properties in the form of copyrights or patents, emerge.

Based on these nature underlying the study of political economy, basic assumptions on the study of political-economy information are arranged. Without any political assumption, the economic-information will assume that the information flow is neutral, given, and always moving smoothly to the decision makers in accordance with the inquiry of each decision maker. However, in reality the truth is not as expected. Homburg (2000) and Homburg and Bekkers (2002), by employing the conceptual framework of political-economy, revealed how the system of information exchange works among organizations, which is not only influenced by the economic factors (the efficiency of resource allocation) but also influenced by political-information like maintaining authority-autonomy instead of information integration for efficiency.

\section{Fiscal Management in Indonesia}

According to Nasution (2009), fiscal management is part of a country's monetary management in the form of a series of activities to plan the budget, to execute, to report and to take a full responsibility for it, and to have it both internally supervised and externally checked by independent bodies. The discussion on fiscal management mainly involves various laws or regulations concerning who does what as well as his/her duties and authorities. In this context, Indonesia's monetary decree has appointed the Minister of Finance as the fiscal authority. Article 6 of the Constitution (Undang Undang) 
Fiscal Management in Indonesia : The Perspective of Political Economy Information

Number 17 of 2003, regarding the Public Finance, states that President as executive and then gives the authority to the Minister of Finance to act as fiscal manager (authority) and the government's representative on fiscal management. The explanation of article 6 also describes that:

"General authorities include the stipulation of direction, public policies, strategy, and priority in the management of the state budget (Anggaran Pendapatan dan Belanja Negara/APBN) for instance in determining the guidelines of state budget's execution and accountability, of the ministry's work plan framing, of the salary and benefit arrangement, and of the management of the country's revenue. ...

Specific authorities cover technical decisions/policies regarding state budget management, e.g. a decree of a cabinet meeting on the matter of state budget management, a decree on the details of the state budget, a decree on the fund balance, and the obliteration of the state's assets and claims."

Article 8 of the Monetary Constitution then organizes necessary functions to implement the authorities, i.e. (1) arranging fiscal policies and macro economy framework; (2) arranging state budget plans and its changes; (3) endorsing documents of budget enforcement; (4) entering into international agreements in monetary matters; (5) collecting the state revenue as declared by the Constitution; (6) performing the function as the nation's general treasury; (7) making financial report as the accountability of state budget ; and (8) performing any other duties in the area of fiscal management based on the Constitution.

Based on this analysis, this study defines fiscal management as part of a country's financial management with the interests of fiscal policies planning, implementing, supervising, and being responsible for them according to the public finance laws or regulation applied in the country.

\section{RESEARCH METHODS}

This study, referring to Walsham (2006); Wahyuni (2010); and Djamhuri (2011), is an interpretative-qualitative study. Moreover, this study employs (1) a case study strategy (Yin, 2009 and Ulfatin, 2014); (2) interpretive policy analysis as the analytical technique and data interpretation (Glynos et al., 2009), and (3) secondary data in the form of various relevant documentations, ranging from official documentation of related institutions to online/offline press releases (Bowen, 2009). 
Following Yin (2009) and Ulfatin (2014), this study uses inter-cases analysis. This analyses technique compares two or more cases to find the possible similarities of pattern. What can be done with the obtained pattern similarities are: (1) applying the "analytical-generalization" (not "statistical generalization") (Yin, 2009); or (2) identifying the existence of "transferability" of the analyzed case to another one (Alwasilah, 2003); or even (3) developing a theory based on the findings of the analyzed case (Eisenhardt, 1989).

This method is conducted to meet the research purpose by focusing on the importance of utilizing the perspective of political-economy information to comprehend certain social/governmental/business phenomena. This study in practice selects the case by considering the magnitude of political-economy information aspects from a particular constellation engaging the society, business sector, or the government.

\section{DISCUSSION: CASE DESCRIPTION AND INTER-CASE ANALYSIS}

The discussion section consists of two parts. First, each case will be outlined briefly by presenting the key issues to obtain an outlook on the existing situation. These key issues then equipped with various relevant contexts so that the political-economy aspects of the situation can be identified and understood. Next, by employing the approach of interpretive policy analysis (Glynos, et al., 2009), this study will construct the obtained outlook with certain interpretation to finally comprehend specific relationship model among variables in every case or inter-cases. The result, in the following stage, is expected to be used as the development of conceptual framework in the study of political-economy information. The case discussed in this study is selected by taking into account the relevance to the problem of study.

\section{Case-1: Development of National Revenue System}

The previous part of this paper has described the rationales of why the analysis of political-economy information is important. What is interesting in relation with the existing situation is for example how the imposition of the national revenue administration system as part of the agreement between Indonesian Government and IMF in the economic recovery program became a keep developing system. 
Fiscal Management in Indonesia : The Perspective of Political Economy Information

Table 1. The Development of National Revenue System

\begin{tabular}{|c|c|c|}
\hline Decree & Substance of Decree & $\begin{array}{c}\text { Important notes related to the } \\
\text { decree }\end{array}$ \\
\hline $\begin{array}{l}\text { KMK (Keputusan } \\
\text { Menteri Keuangan) } \\
\text { No, } \\
\text { 5/KMK.01/1993 }\end{array}$ & $\begin{array}{l}\text { Bank Appointment as } \\
\text { Perception Bank in order } \\
\text { to organize the National } \\
\text { Revenue Deposit }\end{array}$ & $\begin{array}{l}\text { Not explicitely mentioned the existence of } \\
\text { electronic national revenue system }\end{array}$ \\
\hline $\begin{array}{l}\text { KMK } \\
\text { 210/KMK.03/2002 } \\
\text { 455/KMK.04/2002 }\end{array}$ & $\begin{array}{l}\text { Modification to } \\
\text { 5/KMK.01/1993 }\end{array}$ & $\begin{array}{l}\text { To become a Perception bank, it has to: (1) } \\
\text { have data communication network } \\
\text { comprising all concerned bank offices, } \\
\text { (2)have this network connected Directorate } \\
\text { General of Taxation (DJP) and Directorate } \\
\text { General of Treasury; (3) obtain } \\
\text { recommendation from the DJP }\end{array}$ \\
\hline $\begin{array}{l}\text { KMK } \\
\text { 536/KMK.03/2002 } \\
\text { 547/KMK.04/2002 }\end{array}$ & $\begin{array}{l}\text { Modification to } \\
5 / \text { KMK.01/1993 }\end{array}$ & $\begin{array}{l}\text { Perception Bank which has not been able to } \\
\text { meet the requirements as stated in article } 2 \\
\text { subsection (3) can still take the national } \\
\text { revenue deposit until June } 30,2003\end{array}$ \\
\hline $\begin{array}{l}\text { Memorandum of } \\
\text { Economic and } \\
\text { Financial Policies } \\
\text { from the } \\
\text { Government and } \\
\text { Bank of Indonesia } \\
\text { to IMF }\end{array}$ & $\begin{array}{l}\text { Memorandum of Economic } \\
\text { and Financial Policies } \\
\text { (MEFP) }\end{array}$ & $\begin{array}{l}\text { By the end of June, all tax payments have to } \\
\text { be done electronically } \\
\text { By June } 2003 \text {, the electronic tax filing and } \\
\text { payment system will be expanded to } \\
\text { process } 75 \text { percent of DGT tax collections }\end{array}$ \\
\hline $\begin{array}{l}\text { PMK (Peraturan } \\
\text { Menteri Keuangan) } \\
\text { 99/PMK.06/2006 } \\
\text { and its } \\
\text { modifications }\end{array}$ & $\begin{array}{l}\text { Module of the State's } \\
\text { Finance (Modul Keuangan } \\
\text { Negara/MPN) }\end{array}$ & $\begin{array}{l}\text { To complement the decree in KMK Number } \\
5 / \text { KMK.01/1993 regarding the regulation } \\
\text { on how the national revenue system works }\end{array}$ \\
\hline $\begin{array}{l}\text { Constitution No. } \\
28 / 2007\end{array}$ & $\begin{array}{l}\text { Modification to } \\
\text { Constitution No. 6/1983 }\end{array}$ & $\begin{array}{l}\text { Article } 10 \text { subsection (1a) as a decree } \\
\text { which can later acknowledge electronic } \\
\text { information (called as Transaction Number } \\
\text { of National Revenue (Nomor Transaksi } \\
\text { Penerimaan Negara/NTPN) is an } \\
\text { indication that payment made to the pay } \\
\text { office is valid }\end{array}$ \\
\hline $\begin{array}{l}\text { PMK } \\
60 / \text { PMK.05/2011 }\end{array}$ & $\begin{array}{l}\text { Testing of Billing Systems } \\
\text { through MPN }\end{array}$ & $\begin{array}{l}\text { The testing of MPN feature addition which } \\
\text { expands how to pay certain taxes not only } \\
\text { through bank tellers but also through } \\
\text { Automated Teller Machine/ATM, or } \\
\text { internet banking }\end{array}$ \\
\hline
\end{tabular}




\begin{tabular}{|l|l|l|}
\hline \multicolumn{1}{|c|}{ Decree } & Substance of Decree & \multicolumn{1}{c|}{$\begin{array}{c}\text { Important notes related to the } \\
\text { decree }\end{array}$} \\
\hline $\begin{array}{l}\text { PMK } \\
\text { 32/PMK.05/2014 }\end{array}$ & $\begin{array}{l}\text { Electronic System of } \\
\text { National Revenue }\end{array}$ & $\begin{array}{l}\text { The National revenue arranged in this } \\
\text { ministerial decree pervades all the } \\
\text { deposited National Revenue through } \\
\text { Banks/Perception Posts by using Billing } \\
\text { codes }\end{array}$ \\
\hline
\end{tabular}

Source: Author Findings

In the respect of article 7 subsection (2) letter $d$ of the Constitution Number 1 of 2004 concerning the National Treasury, Minister of Finance as the Country's General Treasurer has the authority to determine the system of revenue and expenditure of pay office. To execute this authority, the Minister of Finance has issued a number of decrees which undergo some modifications in line with changes in the encompassing factors. In short, the implementation development of this national administrative revenue system can be illustrated in Table 1. Table 1 shows how policies regarding the system of national revenue have changed from having no interest in the role of information technology to completely depending on information technology-based system.

\section{Case-2: Access to Banking Information by Tax Authority}

Indonesia employs the self-assessment taxation regime. Referring to the general constitution of regulation and Taxation Order (No. 6 of 1983 and its modifications), the self-assessment is basically:

“... in this matter taxation agency, based on its functions, have the duty of development, service, and control to comply with taxation obligation according to what has been stated in the Constitution of Taxation; ...

Taxpayers are trusted to be able to perform national communalism through the system of self-counting, self-calculating, self-paying and self-reporting of the unpaid tax (self assessment) ..."

As a consequence of the decree, tax offices have the authority to find some information as comparison to match with what has been reported by taxpayers through the letter of notification. One of the most important comparison data but up to this point taxation authorities find it difficult to obtain is taxpayer's back account. This is a crucial issue which has yet found solution to satisfy all concerned parties. Indonesian Taxation authorities even ask for this access by referring what is implemented in other countries:

“... will protect the customer's data provided the option of banking data for the interest of tax revenue is opened. He acknowledged that he has asked for some help from 
Organisation for Economic Co-operation and Development (OECD) related to the protection mechanism of the customer's data.

"I demand that the OECD all the possible systems to protect the customers. Thus, people should not be afraid." He said in the Ministry of Finance office, Tuesday, March 11, 2014

... Fuad said that he was surprised with the fact that many parties refused to open the customers' data for the purpose of tax whereas there are many national revenue potentials to uncover.. "If people pay their taxes, why they have to be afraid? If other countries can do this why Indonesia cannot? We are the only one in the world who has not opened banking data for the interest of tax revenue."

Access to bank customers' data to uncover tax potential itself still has to deal with the Constitution of Banking and the Constitution of Defined Regulation and Taxation Order. In the Constitution, access to customer's data is limited to the benefit of investigation in taxation criminal act ..."

(Source: $\quad$ http://www.tempo.co/read/news/2014/03/12/090561483/Buka-DataNasabah-Bank-Pajak-Gandeng-OECD)

On the other hand, however, there are parties who are not willing to give access to the bank account of taxpayers. Undoubtedly with a number of reasons:

"it cannot be given just like that. Is it OK for you if people can easily open your account?" said Harry to Tempo, Tuesday, March 11, 2014. ...

... some changes agreed by the parlement is that the directorate of banking data can be directly held by General Directorate of Taxation upon the delegation the Minister of Finance. Prior to this, inquiry can only be done by the Minister of Finance. "The Minister of Finance can delegate the General Director of taxation to request banking data to the authorities of financial services, " he said.

Besides, if formerly banking data can only be accessed for the interest of an investigation, Harry stated the DPR had agreed in the Draft of Law of Banking that banking data can be accessed for the need of examination, tax collection, and investigation. It can only be inquired provided the Taxation Directorate holds the evidence that one does not pay his taxex based on his profiles."

Harry asserts that Taxation Directorate should also make sure the investigating officer who asks for the customer's data in handling tax case. "if the suspect turns out to be innocent, the tax investigator asking for the the customer's data must keep it confidential for 10 years, " he said. Once it leaks, he confirmed, the investigator faces the risk of 15 years of imprisonment.

The previous Minister of Finance, Muhamad Chatib Basri, requested that access to banking data be opened for taxation interest. In addition to overcoming taxation fraudulence, the automatic data access by the Taxation Directorate increased the potentials of revenue. He asserted that access to banking data for tax interest will not reduce the confidentiality of banking data. "

(Source: $\quad$ http://www.tempo.co/read/news/2014/03/12/092561479/DPR-TolakPembukaan-Rekening-Bank-untuk-Pajak ) 


\section{Case-3: Transparancy and Accountability of the Government Financial}

\section{Management}

The Government Regulation (Peraturan Pemerintah) No.6 of 2008 explained that the financial report and government performance report are needed to implement the transparency and accountability. Before this regulation was put into effect, the accountability report on the national financial management, which was in the form of state/regional budget calculation, did not attach information on the government's wealth and obligation. The reliability of this financial information is insufficient because the accounting system used was not yet based on certain accounting standard.

Based on the publication of General Directorate of Treasury (DJPbn, 2009) related to the development in the use of financial report as the form of financial transparency and accountability, it is important to quote on the following statement:

"Various progresses in accounting and reporting which support a guaranteed transparency and accountability have also been reported by the International Monetary Fund (IMF). Within its report, i.e. Report on Observance of Standards and Codes-Fiscal Transparency Module Indonesia 2006, IMF stated that accounting system in Indonesia has been able to produce a relatively accurate annual report on budget execution. This should be acknowledged as the proof of the Government performance especially in increasing transparancy and accountability. Another appealing phenomena presented in the IMF report is the more complete asset description from year to year. However, the IMF report has also mentioned several issues which still require special attention from the Government, such as the range of financial report which has not included all general government and the significance of various accounting regulations which have not completely guaranteed budget discipline ... "

\section{Case-4: Government Finance Statistics}

Decree in the Constitution No. 1 of 2014 concerning National Treasury explained that to create transparency and accountability in the management of national finance, the government's financial report can also be used to arrange Government Finance Statistics/GFS. Referring to the Ministry of Finance (2013), GFS is a record-keeping mechanism and macroeconomic statistical data presentation designed to support a country's fiscal analysis. It was stated that:

“... GFS uses the principle of accounting and economy in combining statistical data and presenting fiscal data within an analytical framework encompassing the appropriate balancing posts.

...GFS intents on presenting statistical data of the government finance which can help decision makers as well as function as an analytical tool to observe the operational 
development of finance, financial position, and the liquidity condition of governmental sector. ..."

What is interesting to show in this matter is the description used as an example or illustration in the making of statistical report on the government finance:

" ... not less importance is that the consolidation information of the Government Financial Statistic is also used by rating bodies, e.g. Moodys, Standard and Poors, in conducting rating assessment to obligation publishers. This rating assessment will influence investor's decision in investing and will finally affect obligation's interest rate. Owing to reformation in all aspects including in the area of national financial management, Indonesia has gradually become a well-thought-of country in the international economy which is marked by the increasing rank to the level of investment grade, thus, it is safe to say, equal to other developed countries." (DJPbn, 2013).

\section{Inter-Case Analysis}

The four cases mentioned above hold at least two important matters to be revealed further: (1) how the constellation of political-economy is related to the model of allocation, production, and distribution of the national financial information for the interest of technical fiscal management; (2) how the national financial information then has a wider role not only as technical information, but also one that can influence the constellation of national politics and its relation with the global interest.

By referring to the operational definition of political-economy in this study, based on the data and context explained that fiscal management in Indonesia has to be correlated with the global power (for example through multilateral institution like the IMF, or the World Bank). This interest network interplays, whether the domestic interest exploits the the constellation of global finance as a context of decision making, or the opposite where various global interests want to ingrain their influence to the constellation of domestic fiscal management. One of the media to identify the existence of the interplay of the variety of interests is the allocation, production, and distribution (including the issue of ownership and presentation format) of the national financial information. This information, in fact, will be used not only as a helping aid for decision making (technical), but even better, it can also be the trigger for some other interests such as a means of lobbying to be the member of multilateral economic group or reduce the country risk for those who will be drawn to invest their capital. On the basis of the 
four cases explanations above, table 2 illustrates how the political-economy information of fiscal management becomes part of the interplay of the many domestic-global powers and interests.

Table 2. The Interplay model among various aspects of fiscal management in the Poliyical-Economy Information context: an Inter-Case

\begin{tabular}{|c|c|}
\hline Aspects of Fiscal Management & Contexts of Political-Economy Information \\
\hline $\begin{array}{l}\text { Online tax payment system, later } \\
\text { developed into the national } \\
\text { revenue system (such as excise } \\
\text { tax, export duty), with numerous } \\
\text { development on the service } \\
\text { features: via the teller of } \\
\text { perception banks, billing system, } \\
\text { and the ATM }\end{array}$ & $\begin{array}{l}\text { Improvement in the control mechanism of the } \\
\text { national revenue (such as preventing fake tax } \\
\text { report (Surat Setoran Pajak/SSP)), there needs } \\
\text { highlight on how the role of IMF in imposing the } \\
\text { implementation of this as part of the agreement in } \\
\text { the economic recovery program. Nevertheless, in } \\
\text { the following phase, the development of the } \\
\text { various service features related to the national } \\
\text { revenue system is an interaction among many } \\
\text { elements of fiscal management (tax/toll } \\
\text { authority) and the national treasury authority. } \\
\text { Notice the role of global interest here as an } \\
\text { enabler. }\end{array}$ \\
\hline $\begin{array}{l}\text { Efforts to produce the } \\
\text { government financial report } \\
\text { (national/local), and followed by } \\
\text { getting a proper opinion without } \\
\text { exception from the Badan } \\
\text { Pemeriksa Keuangan/BPK as the } \\
\text { external function of the national } \\
\text { financial control }\end{array}$ & $\begin{array}{l}\text { The government financial report arranged by } \\
\text { using administrative accounting standard is a } \\
\text { political decision in the constellation that requires } \\
\text { a separation of power. In a broader context, the } \\
\text { government used this financial report as one of } \\
\text { the powers to be capitalized as a means to } \\
\text { increase the bargaining power with the parlement } \\
\text { in the making of national budget (APBN), } \\
\text { attracting investors or lenders. For the central } \\
\text { government, this ability to produce financial } \\
\text { report is also used to strengthen its position in the } \\
\text { economic diplomacy. The global interest that } \\
\text { needs to be analyzed in this context is that it will } \\
\text { be easier for them to obtain the national financial } \\
\text { information as their analytical tool in making } \\
\text { decision (political-economy) with Indonesia. }\end{array}$ \\
\hline
\end{tabular}




\begin{tabular}{|c|c|}
\hline $\begin{array}{l}\text { The making of the government } \\
\text { financial statistics as the } \\
\text { information integration of the } \\
\text { central and local government's } \\
\text { financial report as an effort to } \\
\text { present information to support } \\
\text { the analysis of macro economy. }\end{array}$ & $\begin{array}{l}\text { Treasury authority arranges the Government } \\
\text { Financial Statistic as an effort to increase } \\
\text { transparency and accountability of the } \\
\text { government's because they have integrated } \\
\text { information presented in both the central and } \\
\text { local financial reports. This statistic refers to the } \\
\text { GFS Manual which means that the information } \\
\text { presentation is not merely for the interest of } \\
\text { information users in the area of domestic fiscal } \\
\text { authority but for consideration and for trying to } \\
\text { reach global interest }\end{array}$ \\
\hline $\begin{array}{l}\text { Information access to taxpayers' } \\
\text { accounts by taxation authority as } \\
\text { the consequence of self- } \\
\text { assessment taxation system. }\end{array}$ & $\begin{array}{l}\text { Global interest seems to be of little help in the } \\
\text { effort of fiscal authority to obtain legal-social } \\
\text { context in its effort to get a broader and easier } \\
\text { access to banking data for the benefit of tax } \\
\text { administration. Fiscal authority is likely to be on } \\
\text { its own in its attempt to get the access. Based on } \\
\text { the explained cases, it can be seen that global } \\
\text { interest is not really enthusiastic in encouranging } \\
\text { the issue of banking information access to be a } \\
\text { policy which can be concretely implemented, } \\
\text { compared to their effort in urging the } \\
\text { implementation of control system in the national } \\
\text { revenue or integration of the government's } \\
\text { financial report information. }\end{array}$ \\
\hline
\end{tabular}

Source: Author Analysis.

\section{CONCLUSION}

This study attempts to provide a new perspective by emphasizing that the flow of national financial information necessary to support the achievement of fiscal stability and it is not simply a matter of economic-information as a process of information allocation, production, distribution, and consumption. Therefore the economicinformation that also applicable in fiscal management is true. In the implementation of tax payment system for example, it is obvious that the technical reason for the implementation is the efficiency of data management and the facilitation of control. Hovever, it is undeniable how the initiative can be executed is a very political idea. It is probably beyond one's conception before that such detailed and technical matter on collecting and presenting information regarding the national revenue, later becomes part of how a country negotiates with international donor institution. This situation reaffirm that the provision of the national financial information proper for decision 
making in fiscal management colored by the trade-offs of various domestic political interests, including the the relationship between central and local, competition among interest groups, or action-reaction to the interest of global politics, be it through the capital market (national debenture market) or through international monetary institutions.

In the perspective of political-economy information, the intercase analysis reveals that in order to provide information regarding the reliable national finance to attain a good fiscal management, a proper political support is required. To make national financial information benefit of fiscal management, there must be an interaction between political-actors with interest in allocation, production, and as part of power interplay of these actors toward "economic-cake" of national budget or APBN. As a closing (as well as as a recommendation), by using the perspective of political-economy information, it can be stated that: national financial information owned by fiscal authority should be able to be used for technical interests (managerial functions) of the fiscal management itself; moreover, fiscal authority should be able to capitalize the information as a support to other governmental interests, like increasing the bargaining power in the economic diplomacy.

\section{REFERENCES}

Alwasilah, A. C. (2003), Pokoknya Kualitatif Dasar-dasar Merancang dan Melakukan Penelitian Kualitatif. Bandung: Kiblat Buku Utama.

Benkler, Y. (2003), Freedom in the Commons: Towards a Political Economy of Information, Duke Law Journal, 52(6), 1245-76.

Bowen, G. A. (2009), Document Analysis as a Qualitative Research Method, Qualitative Research Journal, 9(2), 27-40.

Davenport, T. H., Eccles, R. G., and Prusak, L. (1992), Information Politics, Sloan Management Review.

Deliarnov (2006), Ekonomi Politik. Jakarta, Erlangga.

Djamhuri, A. (2011). Ilmu Pengetahuan Sosial dan Berbagai Paradigma dalam Kajian Akuntansi. Jurnal Akuntansi Multiparadigma, 2(1), 147-85.

DJPbn. (2009). Peningkatan Transparansi dan Akuntabilitas Pengelolaan Keuangan Negara melalui Akuntansi dan Pelaporan Keuangan Pemerintah tahun 2004-2009. Direktorat Jenderal Perbendaharaan (DJPbn).

. (2013). Petunjuk Teknis Penyusunan Laporan Keuangan Pemerintahkonsolidasian Tingkat Wilayah Dan Laporan Statistikkeuangan Pemerintah Tingkat Wilayah Pada 
Kantor Wilayahdirektorat Jenderal Perbendaharaan. Direktorat Jenderal Perbendaharaan.

Eisenhardt, K. M. (1989). Building Theories from Case Study Research. The Academy of Management Review, 14(4), 532-50.

Glynos, J., Howarth, D., Norval, A., and Speed, E. (2009), Discourse Analysis: Varieties and Methods. ESRC National Centre for Research Methods Review.

Homburg, V. (2000), The Political Economy of Information Exchange Politics and Property Rights in the Development and Use of Interorganizational Information Systems, Knowledge, Technology, \& Policy,, Fall 2000,VoI. 13(3), 49-66.

Homburg, V., and Bekkers, V. (2002), The Back-Office of E-Government (Managing Information Domains as Political Economies)". 35th Hawaii International Conference on System Sciences. Hawaii.

IMF (2003) Letter of Intent, Memorandum of Economic and Financial Policies, and Technical Memorandum of Understanding. accesses at 30 January 2013. URL: http://www.imf.org/external/np/loi/2003/idn/01/

Kemenkeu (2013), Peraturan Menteri Keuangan Republik Indonesia Nomor 214/PMK.05/20113 tentang Bagan Akun Standar.

Kompas (2003), Hindari Informasi yang Asimetris: ISEI soal Pengakhiran Program IMF. Kompas. Jakarta: Kompas,

Nasution, A. (2009), Perbaikan Transparansi dan Akuntabilitas Pengelolaan Keuangan Negara dan Daerah di Indonesia. Accessed at 5 September 2014. URL: http://www.bpk.go.id/assets/files/attachments/2009/04/dialog-publikmanado2.pdf

O'Brien, R., C., and Helleiner, G., K (1980) The Political Economy of Information in a Changing International Economic Order, International Organization, 34(4), 44570.

Oppenheimer, J. A. (1980), Small Steps Forward for Political Economy, World Politics, 33(1), 121-51.

Porat, M. U. (1977), Information Economy: Definition and Measurements. Washington, D.C.: US Office of Telecommunications - National Science Foundation.

Sadli, M. (2003), ISEI dan "Exit Strategy" dari IMF. URL: http://www.kompas.com/kompas-cetak/0307/16/opini/432837.htm

Salter, L. (1993), Have We Reached the Information Age Yet? International Journal of Political Economy, 23(4), 3-25.

Strassmann, P. A. (1994), The Politics of Information Management: Policy Guidelines. Information Economic Press.

Ulfatin, N. (2014) Metode Penelitian Kualitatif di Bidang Pendidikan. Malang: Bayumedia Publishing.

Verzola, R., (2006), Information Economy. Accessed at 17 Agustus 2014. URL: http://vecam.org/article724.html 
Wahyuni (2010), Paradigma Kualitatif-Interpretif dalam Penelitian Bidang Sistem Informasi. Journal of Information Technology and Electrical Engineering, 1(1), 1-5.

Walsham, G. (2006), Doing interpretive research. European Journal of Information Systems 15, 320-330, 15, 320-30.

World Bank (2008) The Political Economy of Policy Reform: Issues and Implications for Policy Dialogue and Development Operations. Social Development Department Environmentally and Socially Sustainable Development Network The World Bank.

Yin, R. K. (2009), Studi Kasus: Desain dan Metode (terjemahan M. Djauzi Mudzakir). Jakarta: Rajawali Pers. 